\title{
Induced Pluripotent Stem Cell-related Genes Correlate With Poor Prognoses of Oral Squamous Cell Carcinoma
}

\author{
YUMI MURAKI ${ }^{1}$, TAKUMI HASEGAWA ${ }^{1}$, DAISUKE TAKEDA ${ }^{1}$, TAKESHI UEHA ${ }^{2}$, EIJI IWATA ${ }^{1}$, \\ IZUMI SAITO $^{1}$, RIKA AMANO ${ }^{1}$, AKIKO SAKAKIBARA ${ }^{1}$, MASAYA AKASHI ${ }^{1}$ and TAKAHIDE KOMORI ${ }^{1}$ \\ ${ }^{1}$ Department of Oral and Maxillofacial Surgery, Kobe University Graduate School of Medicine, Kobe, Japan; \\ ${ }^{2}$ Department of Rehabilitation Medicine, Kobe University Graduate School of Medicine, Kobe, Japan
}

\begin{abstract}
Background/Aim: We recently investigated the contribution of the iPS-related genes SOX2, OCT4, and Nanog to de-differentiation by assaying for their $m R N A$ levels. Given that mRNA expression does not always correlate with the protein levels, the aim of this study was to retrospectively determine the expression of these four iPS-related factors in human OSCC specimens by immunohistochemistry and examine their association with patient prognosis. Materials and Methods: iPS cell-related gene expression in 89 OSCC patients by tissue microarray, and its correlation with clinicopathological factors, differentiation, metastasis, and poor prognoses were investigated. Results: No evidence of statistically significant relationships was found between the expression of iPS cellrelated genes and clinicopathological parameters. However, our data indicated that KLF4 expression was associated with survival, and poor tumor differentiation. In addition, high expression of KLF4 was an independent poor prognostic factor ( $p=0.004$ ) for OSCC patients. Conclusion: In preoperative biopsies, higher KLF4 and poor differentiation may be clinically effective predictors for the prognosis of oral cancer.
\end{abstract}

Oral squamous cell carcinoma (OSCC) is a malignancy characterized by genomic instability and dysregulated cell growth attributable to oncogene overexpression, repression of tumor-suppressor genes, and other genetic, epigenetic, and microRNA alterations (1). These changes are associated with poor prognosis in patients with OSCC,

Correspondence to: Takumi Hasegawa, D.D.S., Ph.D., Department of Oral and Maxillofacial Surgery, Kobe University Graduate School of Medicine, 7-5-1 Kusunoki-cho, Chuo-ku, Kobe 6500017, Japan. Tel: +81 783826213, Fax: +81 783826229, e-mail: hasetaku@med.kobe-u.ac.jp

Key Words: Squamous cell carcinoma, induced pluripotent stem cells, reprogramming factors, iPS cell-related factors, kruppel-like factor 4. especially when locoregional recurrence or metastasis to regional lymph nodes or distant sites are present (2). However, the mechanisms of metastasis and recurrence in OSCC remain unclear.

Stem cells have the ability to self-renew and generate mature cells with different fates in tissues and are currently in focus for their role in cancer biology. Cancer stem cells (CSCs) share some of the fundamental features of normal stem cells, such as self-renewal and differentiation capacity, and are thus thought to contribute to tumor recurrence and resistance to therapy (3-6).

Induced pluripotent stem (iPS) cells have been shown to acquire pluripotency following the introduction of four transcriptional factors: octamer-binding transcription factor 4 (OCT4), sex determining region Y-box 2 (SOX2), avian myelocytomatosis viral oncogene (C-myc), and Kruppel-like factor 4 (KLF4), which can also induce pluripotency in embryonic or adult murine fibroblasts $(7,8)$. These pluripotency-inducing factors have been shown to play an important role in embryonic stem cells, normal stem cells, and CSCs, including in OSCC (9). While necessary for the acquisition of pluripotency, it has also been suggested that these factors may have an oncogenic potential (10).

Although the status and functional roles of these genes in CSCs have not been elucidated for all malignancies, their expression is associated with several types of cancers, including esophageal, colon, lung, and bladder cancers (11-14).

We recently investigated the contribution of the iPSrelated genes $S O X 2$, OCT4, and Nanog to de-differentiation by assaying for their mRNA level (5). OCT4 and SOX2 mRNA is expressed in esophageal squamous carcinoma cell lines (15), while KLF4 and $C$-myc mRNA is elevated in dysplastic epithelium and laryngeal and oral SCC (16).

Given that mRNA expression does not always correlate with the protein levels, we retrospectively determined the expression of these four iPS-related factors in human OSCC specimens by immunohistochemistry and examined its association with patient prognosis. 


\section{Materials and Methods}

Patients and clinical specimens. Eighty-nine patients with OSCC were retrospectively included in this study. All underwent surgical resection at the Department of Oral and Maxillofacial Surgery, Kobe University Hospital between July 2011 and December 2013 and were followed up until August 2017. Clinical and pathological data were retrospectively collected from the hospital records. All participants received clinical treatment according to consensus guidelines for head and neck cancers [UICC classification, 7th edition (2009)]. Each patient underwent surgical excision of tumors with a clear $10-\mathrm{mm}$ margin from the tumor edge. All tumor specimens were independently processed by two experienced pathologists. The protocol for this study was approved by the Ethics Committee of Kobe University. Because of the retrospective nature of this study, informed consent was not required. Instead, patients were given the opportunity to refuse use of their samples in this study.

Histopathology and immunohistochemistry. Formalin-fixed paraffin-embedded tumor sections were prepared at the department of pathology of our hospital and cut into $4-\mu \mathrm{m}$ sections. The sections were subsequently deparaffinized in xylene and rehydrated in a graded alcohol series, washed three times for $3 \mathrm{~min}$ in phosphate buffered saline (PBS), and subjected to antigen retrieval by proteinase $\mathrm{k}$ treatment (Dako, Carpinteria, CA, USA) for $15 \mathrm{~min}$ prior to blocking of endogenous peroxidase activity by incubation with $3 \% \mathrm{H}_{2} \mathrm{O}_{2}$ for $10 \mathrm{~min}$ at room temperature. Following two 5min washes in PBS, the sections were incubated overnight at $4^{\circ} \mathrm{C}$ with the following primary antibodies in Can Get Signal Immunostain Solution A (Toyobo, Osaka, Japan): polyclonal rabbit antimouse/human OCT4 (\#09-0023; STEMGENT, Cambridge, MA, USA), polyclonal rabbit anti-mouse/human SOX2 (\#09-0024; STEMGENT), monoclonal rabbit anti-mouse/rat/human C-myc (\#ab32072; Abcam, Cambridge, UK), and monoclonal mouse antimouse/human KLF4 (\#09-0021; STEMGENT). The antibodies were used at the following dilutions: SOX2, 1:100; KLF4, 1:100; OCT4, 1:100; and C-myc, 1:100. Following three 3-min washes in PBS after primary antibody treatment, sections were incubated with horseradish peroxidase (HRP)-conjugated anti-rabbit IgG polyclonal antibody (\#424142; Nichirei Bioscience, Tokyo, Japan) or anti-mouse IgG polyclonal antibody (\#424132; Nichirei Bioscience) for $120 \mathrm{~min}$ at room temperature without dilution. Following three 3-min washes in PBS, the signal was developed as a brown reaction product using the peroxidase substrate 3,3diaminobenzidine (\#415171; Nichirei Bioscience) for $5 \mathrm{~min}$ at room temperature. Following two 3-min washes in distilled water, sections were counterstained with hematoxylin for $4 \mathrm{~min}$ and images were captured using a BZ-X700 confocal microscope (Keyence Corporation, Osaka, Japan). Cancerous tissues and normal epithelium were imaged by light microscopy at $\times 200$ magnification for each patient. The expression of each factor was determined independently, and cancerous and normal tissues were scored using BZ-H3C/Hybrid cell count (Keyence, Osaka, Japan). Finally, the percentages of stained cells in cancerous versus normal tissues was calculated.

Sets of normal and cancerous tissues from the same patient were selected and stained simultaneously to standardize the controls, for the analysis of expression of each of the four genes. The discriminatory ability of iPS-related gene intensity (high $v s$. low expression) as an
Table I. Percentages of positively-stained cells in cancerous versus normal tissues.

\begin{tabular}{lccc}
\hline & \multicolumn{3}{c}{ Positive stained nuclei, \% } \\
\cline { 2 - 4 } Factor & Low & Cutoff values $^{\mathrm{a}}$ & High \\
\hline SOX2 & $\leq$ & 100.5 & $<$ \\
KLF4 & $\leq$ & 118.1 & $<$ \\
OCT4 & $\leq$ & 102.4 & $<$ \\
C-myc & $\leq$ & 106.7 & $<$ \\
\hline
\end{tabular}

aCutoff values were determined by a receiving operating characteristic curve.

indicator of disease-specific survival (DSS) was evaluated using a receiving operating characteristic (ROC) curve to determine the cutoff values for clinical tests. The area under the curve (AUC) was used to measure the accuracy of this discrimination and ranged from 0.5 to 1 . Cutoff values were selected to minimize the number of false positive and false negative results. The expression levels of the iPS-related factors were used to determine the cutoff values for low and high expression using the ROC curve method described above. The cutoff values for SOX2, KLF4, OCT4, and C-myc were $100.5 \%, 118.1 \%$, $102.4 \%$, and $106.7 \%$, respectively (Table I). Representative immunohistochemistry results are shown in Figure 1.

Statistical analysis. SPSS 22.0 (IBM, Armonk, NY, USA) and Ekuseru-Toukei 2012 (Social Survey Research Information Co., Ltd., Tokyo, Japan) software were used for all statistical analyses. Associations of each variable were analyzed by Fisher's exact test or the chi-square test for categorical variables. Associations between preoperative variables, including iPS-related genes (SOX2, KLF4, OCT4, C-myc), with DSS were introduced into a multiple logistic regression model. Forward stepwise algorithms were used to reject variables that did not significantly fit the model. Odds ratios (ORs) and $95 \%$ confidence intervals (CIs) were calculated, and overall survival (OS), DSS, distant metastasis (DM), and local control (LC) rates following surgery were estimated for each group using the Kaplan-Meier method, with differences assessed using the log-rank test. For all analyses, a value of $p<0.05$ was considered to indicate statistical significance.

\section{Results}

Patient characteristics. Clinical characteristics of enrolled patients with OSCC are summarized in Table II. Among the 89 patients, 51 were male $(57.3 \%)$ and 38 were female $(42.7 \%)$, and the mean age was $66.7 \pm 14.2$ years (range $=22$ 88 years). Clinical $\mathrm{T}$ classifications were $\mathrm{T} 1$ in 28 patients (31.5\%), T2 in 36 patients $(40.4 \%)$, T3 in 9 patients $(10.1 \%)$, $\mathrm{T} 4 \mathrm{a}$ in 13 patients $(14.6 \%)$, and $\mathrm{T} 4 \mathrm{~b}$ in 3 patients $(3.4 \%)$. The most common primary tumor site was the tongue (46 patients $/ 51.7 \%$ ). The 3-year disease control status was local recurrence in 12 patients $(13.5 \%)$, regional recurrence in 20 patients $(22.5 \%)$, DM in 9 patients $(10.1 \%)$, and diseasespecific death in 8 patients $(9.0 \%)$ (Table II). 

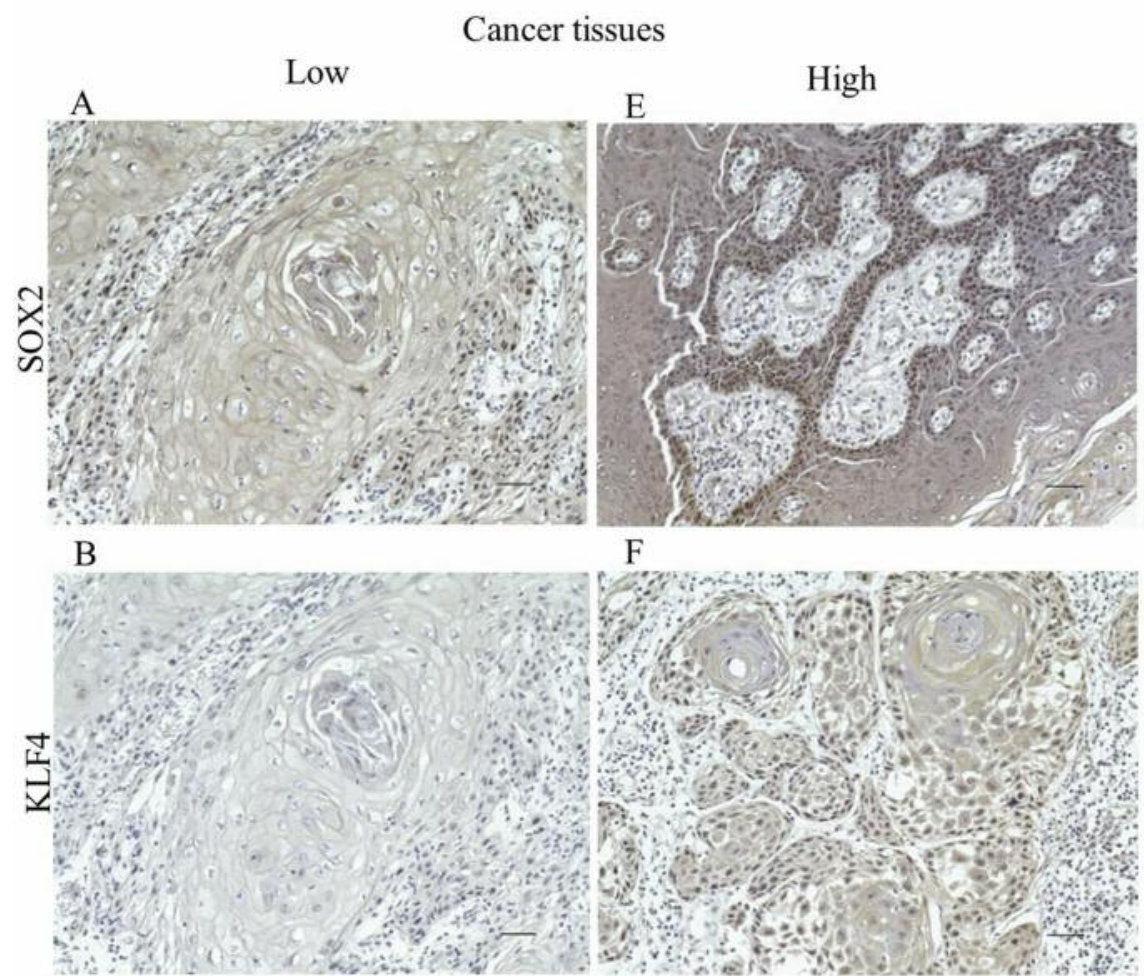

F

Normal tissues
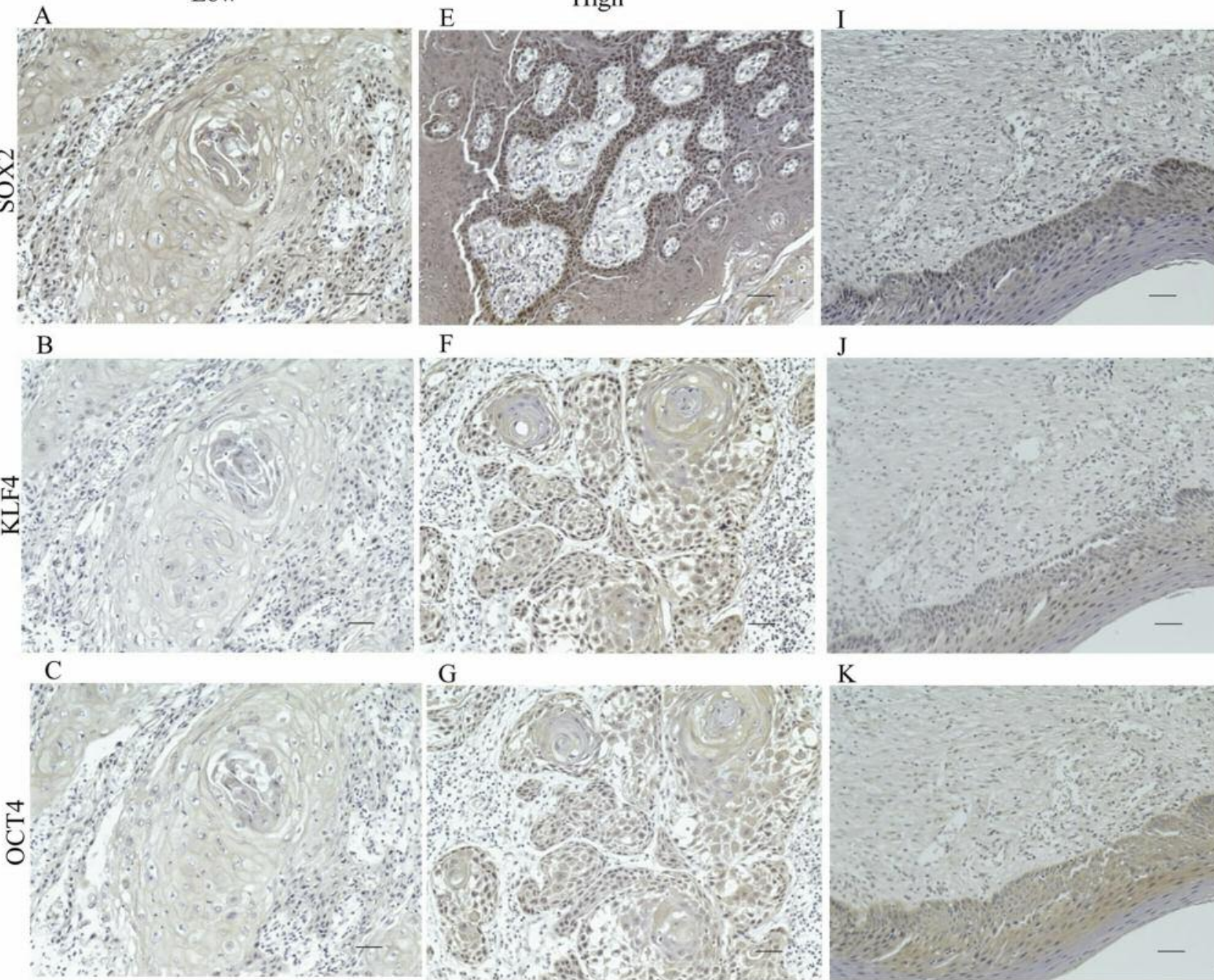

G

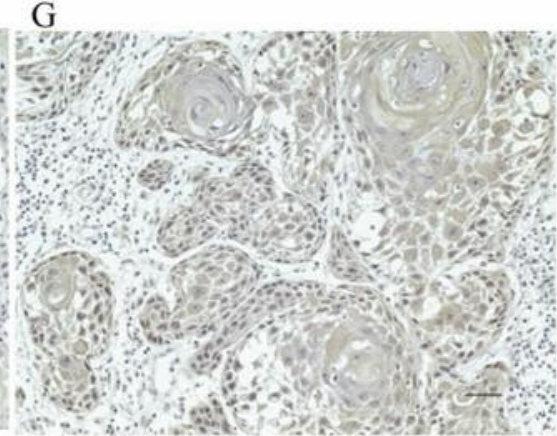

D

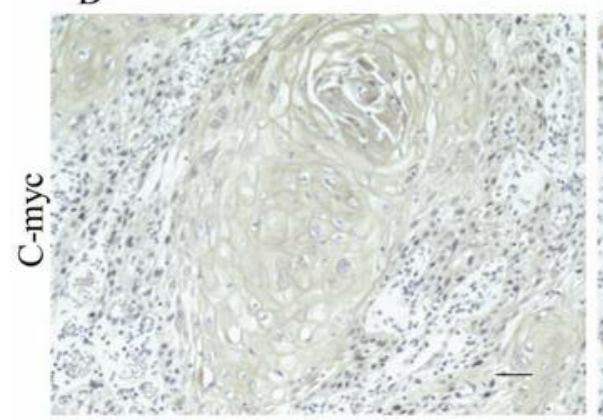

$\mathrm{H}$

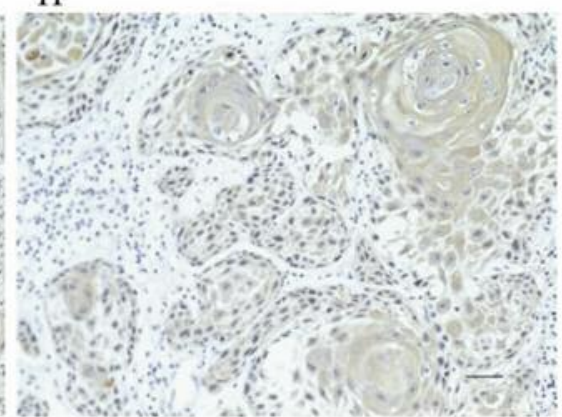

J

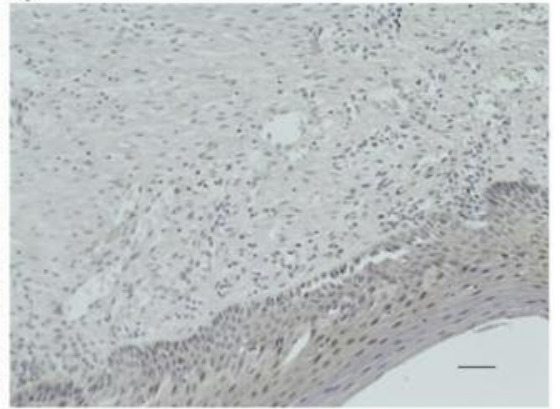

K

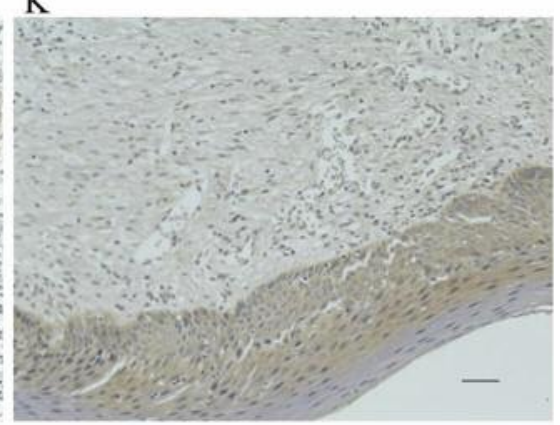

L

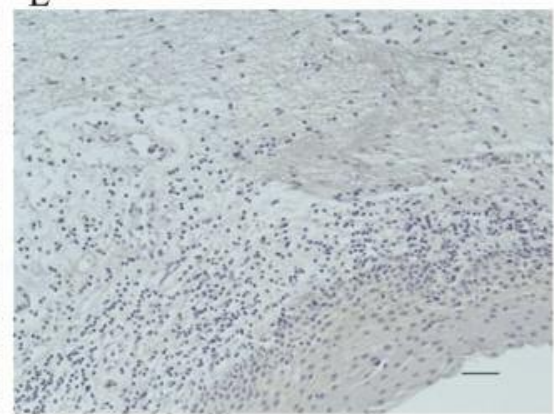

Figure 1. Expression levels of iPS-related genes SOX2, KLF4, OCT4, and C-myc by immunohistochemistry. Images show representative examples of low expression $(A-D)$, high expression $(E-H)$, and normal epithelium $(I-L)$; magnification: $\times 200$. Scale bar, $50 \mu m$.

Expression of iPS-related genes. iPS-related genes are predominantly localized to the nucleus of OSCC cells, and immunostaining of the four proteins examined in our study
(SOX2, KLF4, OCT4, and C-myc) showed that they were primarily expressed in nuclei. However, in some instances, the nuclei and cytoplasm were stained to the same degree 
with antibodies against SOX2, KLF4, and OCT4 in OSCC cells. All four proteins were also detected in normal basal epithelial cells (Figure 1).

Association between the expression of iPS-related genes and clinicopathological factors. Next, the associations between these transcription factors and clinicopathological factors were investigated (Table III). KLF4 and C-myc expression were significantly associated with age $(p=0.019$ and $p<0.001$, respectively) and exposure to tobacco ( $p=0.016$ and $p=0.036$, respectively), while SOX2 and OCT4 showed no statistically significant associations with these factors. OCT4 expression was significantly higher in patients with multiple neck metastases than in patients without multiple neck metastases $(p=0.020)$. Additionally, OCT4 expression was significantly higher in patients with moderate or poor differentiation than in those with well-differentiated tumors $(p=0.044)$. There were no statistically significant relationships between the iPSrelated factors and other clinicopathological parameters, including alcohol, clinical $\mathrm{T}$ stage, clinical $\mathrm{N}$ stage, PS, primary tumor site, or extra nodal extension (ENE).

Correlation between iPS-related genes and survival rates. The 3 -year OS rates of patients with high KLF4 and OCT4 expression were significantly decreased compared to those with low expression ( $p=0.002$ and $p=0.015$, respectively) (Figures 2-3). The 3-year DSS rates of patients with highKLF4, OCT4, and SOX2 expression were significantly decreased compared with those exhibiting low expression $p<0.001, p=0.010$, and $p=0.007$, respectively) (Figures 2-4). Regarding 3-year LC rates, high KLF4 expression was associated with a decreased rate compared with low expression $(p=0.012)$ (Figure 2). Finally, the 3-year DM rates of patients with high KLF4, OCT4, SOX2, and C-myc expression were decreased compared to those exhibiting low expression $(p<0.001$, $p=0.030, p=0.004$, and $p<0.001$, respectively) (Figures 2-5). Multivariate analysis also revealed that KLF4 $(\mathrm{OR}=10.28)$ and tumor differentiation $(\mathrm{OR}=14.85)$ were the most predictive factors for DSS $(p=0.004)$ (Table IV).

\section{Discussion}

In recent years, stem cells have been identified in most tissue types, and CSCs have been hypothesized to enable metastasis. Research to identify the genetic changes leading to cancer has led to major advances in CSC biology (3). iPS technology (the mechanism of action of iPS-related factors) has been demonstrated in mouse fibroblasts by reprograming with four transcription factors, SOX2, KLF4, OCT4, and Cmyc, with Nanog now reported to be less relevant (7), and the possibility of these iPS-related genes being associated with malignant transformation has been proposed (10). For example, KLF4 has been associated with both tumor
Table II. Clinicopathological characteristics of the 89 oral squamous cell carcinoma patients.

\begin{tabular}{|c|c|c|}
\hline Characteristics of patients & $\begin{array}{l}\text { No. of } \\
\text { patients }\end{array}$ & $(\%)$ \\
\hline \multicolumn{3}{|l|}{ Age, years } \\
\hline$<65$ & 34 & 38.2 \\
\hline$\geq 65$ & 55 & 61.8 \\
\hline \multicolumn{3}{|l|}{ Gender } \\
\hline Male & 51 & 57.3 \\
\hline Female & 38 & 42.7 \\
\hline \multicolumn{3}{|l|}{ Exposure to tobacco } \\
\hline Smoker & 27 & 30.3 \\
\hline Non & 62 & 69.7 \\
\hline \multicolumn{3}{|l|}{ Exposure to alcohol } \\
\hline Drinker & 39 & 43.8 \\
\hline Non & 50 & 56.2 \\
\hline \multicolumn{3}{|l|}{ PS } \\
\hline$\leq 1$ & 82 & 92.1 \\
\hline$>2$ & 7 & 7.9 \\
\hline \multicolumn{3}{|l|}{ Primary tumor site } \\
\hline Upper gingiva & 9 & 10.1 \\
\hline Lower gingiva & 16 & 18.0 \\
\hline Buccal mucosa & 6 & 6.7 \\
\hline Tongue & 46 & 51.7 \\
\hline Oral floor & 12 & 13.5 \\
\hline Palate & 0 & 0 \\
\hline \multicolumn{3}{|l|}{ Clinical T stage } \\
\hline I & 28 & 31.5 \\
\hline II & 36 & 40.4 \\
\hline III & 9 & 10.1 \\
\hline IVA/B & 16 & 18.0 \\
\hline \multicolumn{3}{|l|}{ Clinical N stage } \\
\hline 0 or I & 67 & 75.3 \\
\hline II or III & 22 & 24.7 \\
\hline \multicolumn{3}{|l|}{ ENE } \\
\hline Positive & 13 & 14.6 \\
\hline Negative & 26 & 29.2 \\
\hline Non-lymph node metastasis, Non-neck dissection & 50 & 56.2 \\
\hline \multicolumn{3}{|l|}{ Multiple neck metastasis } \\
\hline Positive & 18 & 20.2 \\
\hline Negative & 37 & 41.6 \\
\hline Non-neck dissection & 34 & 38.2 \\
\hline \multicolumn{3}{|l|}{ Margin } \\
\hline Positive & 25 & 28.1 \\
\hline Negative & 64 & 71.9 \\
\hline \multicolumn{3}{|l|}{ Tumor differentiation } \\
\hline Well & 57 & 64.1 \\
\hline Moderate & 27 & 30.3 \\
\hline Poor & 4 & 4.5 \\
\hline Others & 1 & 1.1 \\
\hline \multicolumn{3}{|l|}{ Disease control status } \\
\hline Survival & 71 & 79.8 \\
\hline Local recurrence & 12 & 13.5 \\
\hline Regional recurrence & 20 & 22.5 \\
\hline Distant metastasis & 9 & 10.1 \\
\hline Disease specific death & 8 & 9.0 \\
\hline
\end{tabular}

ENE: Extra nodal extension. 
Table III. Clinicopathological characteristics of the 89 patients according to the expression of each gene.

\begin{tabular}{|c|c|c|c|c|c|c|c|c|c|c|c|c|c|}
\hline & \multicolumn{4}{|c|}{ SOX2 expression } & \multicolumn{3}{|c|}{ KLF4 expression } & \multicolumn{3}{|c|}{ OCT4 expression } & \multicolumn{3}{|c|}{$C-m y c$ expression } \\
\hline & $\mathrm{n}$ & $\begin{array}{l}\text { Low } \\
(\mathrm{n} ; \%)\end{array}$ & $\begin{array}{l}\text { High } \\
(\mathrm{n} ; \%)\end{array}$ & $p$-Value & $\begin{array}{l}\text { Low } \\
(\mathrm{n} ; \%)\end{array}$ & $\begin{array}{l}\text { High } \\
(\mathrm{n} ; \%)\end{array}$ & $p$-Value & $\begin{array}{l}\text { Low } \\
(\mathrm{n} ; \%)\end{array}$ & $\begin{array}{l}\text { High } \\
(\mathrm{n} ; \%)\end{array}$ & $p$-Value & $\begin{array}{l}\text { Low } \\
(\mathrm{n} ; \%)\end{array}$ & $\begin{array}{l}\text { High } \\
(\mathrm{n} ; \%)\end{array}$ & $p$-Value \\
\hline Age,years & & & & 0.051 & & & $0.019^{*}$ & & & 0.193 & & & $<0.001 *$ \\
\hline$<65$ & 34 & 11 & 23 & & 21 & 13 & & 16 & 18 & & 10 & 24 & \\
\hline$\geq 65$ & 55 & 30 & 25 & & 47 & 8 & & 34 & 21 & & 39 & 16 & \\
\hline Gender & & & & 0.390 & & & 0.076 & & & 0.390 & & & 0.397 \\
\hline Male & 51 & 21 & 30 & & 35 & 16 & & 28 & 23 & & 26 & 25 & \\
\hline Female & 38 & 20 & 18 & & 33 & 5 & & 22 & 16 & & 23 & 15 & \\
\hline Exposure to tobacco & & & & 0.165 & & & $0.016^{*}$ & & & 0.646 & & & $0.036^{*}$ \\
\hline Smoker & 27 & 9 & 18 & & 16 & 11 & & 14 & 13 & & 10 & 17 & \\
\hline Non & 62 & 32 & 30 & & 52 & 10 & & 36 & 26 & & 39 & 23 & \\
\hline Exposure to alcohol & & & & 1.000 & & & 1.000 & & & 0.397 & & & 0.391 \\
\hline Drinker & 39 & 18 & 21 & & 30 & 9 & & 24 & 15 & & 19 & 20 & \\
\hline Non & 50 & 23 & 27 & & 38 & 12 & & 26 & 24 & & 30 & 20 & \\
\hline PS & & & & 0.241 & & & 0.666 & & & 0.461 & & & 1.000 \\
\hline 0 or 1 & 82 & 36 & 46 & & 63 & 19 & & 45 & 37 & & 45 & 37 & \\
\hline More than 2 & 7 & 5 & 2 & & 5 & 2 & & 5 & 2 & & 4 & 3 & \\
\hline Primary tumor site & & & & 0.673 & & & 0.139 & & & 0.831 & & & 0.671 \\
\hline Tongue & 46 & 20 & 26 & & 32 & 14 & & 25 & 21 & & 24 & 22 & \\
\hline Otherwise & 43 & 21 & 22 & & 36 & 7 & & 25 & 18 & & 25 & 18 & \\
\hline Clinical T stage & & & & 1.000 & & & 0.407 & & & 1.000 & & & 0.639 \\
\hline $\mathrm{T} 1, \mathrm{~T} 2$ & 64 & 29 & 35 & & 47 & 17 & & 36 & 28 & & 34 & 30 & \\
\hline $\mathrm{T} 3, \mathrm{~T} 4$ & 25 & 12 & 13 & & 21 & 4 & & 14 & 11 & & 15 & 10 & \\
\hline Clinical N stage & & & & 1.000 & & & 1.000 & & & 0.808 & & & 0.806 \\
\hline 0 or 1 & 67 & 31 & 36 & & 51 & 16 & & 37 & 30 & & 36 & 31 & \\
\hline$>2$ & 22 & 10 & 12 & & 17 & 5 & & 13 & 9 & & 13 & 9 & \\
\hline ENE & & & & 0.495 & & & 0.157 & & & 0.734 & & & 0.307 \\
\hline Positive & 13 & 4 & 9 & & 6 & 7 & & 5 & 8 & & 4 & 9 & \\
\hline Negative & 26 & 12 & 14 & & 19 & 7 & & 13 & 13 & & 14 & 12 & \\
\hline Multiple neck metastasis & & & & 0.774 & & & 0.115 & & & $0.020 *$ & & & 0.391 \\
\hline Positive & 18 & 7 & 11 & & 10 & 8 & & 5 & 13 & & 7 & 11 & \\
\hline Negative & 37 & 17 & 20 & & 29 & 8 & & 24 & 13 & & 20 & 17 & \\
\hline Tumor differentiation & & & & 0.271 & & & 0.801 & & & $0.044 *$ & & & 0.125 \\
\hline Well & 57 & 29 & 28 & & 44 & 13 & & 37 & 20 & & 35 & 22 & \\
\hline $\begin{array}{l}\text { Moderate, Poor, } \\
\text { Others }\end{array}$ & 32 & 12 & 20 & & 24 & 8 & & 13 & 19 & & 14 & 18 & \\
\hline
\end{tabular}

*Statistically significant $(p<0.05)$. ENE: Extra nodal extension.

suppression and oncogenesis $(17,18,19)$, with increased expression reported in human head and neck squamous cell carcinoma (HNSCC) and breast cancer, and KLF4 has been demonstrated to be a poor prognostic factor in skin cancer and early breast cancer (20). SOX2 and OCT4 are important for the enhancement of self-renewal and pluripotency in pluripotent stem cells $(21,22)$. C-myc is an oncogenic transcription factor involved in the regulation of cell proliferation, differentiation, and apoptosis, and it also plays an important regulatory role in the activity of genes involved in cell division $(16,23)$.

Therefore, the expression of iPS-inducing factors in human OSCC specimens was investigated by immunohistochemistry, and the associations between these factors and patient prognosis were analyzed.
Table IV. Predictive factors for disease-specific survival in oral squamous cell carcinoma patients by multivariate analysis.

\begin{tabular}{lcrrr}
\hline & & \multicolumn{2}{c}{$95 \% \mathrm{CI}$} & \\
\cline { 3 - 4 } Disease specific survival & Odds ratio & Lower & Upper & p-Value \\
\hline KLF4 & 10.28 & 2.069 & 51.098 & $0.004^{*}$ \\
Tumor differentiation & 14.85 & 1.822 & 120.943 & $0.012^{*}$ \\
\hline
\end{tabular}

*Statistically significant $(p<0.05)$. CI: Confidence interval.

A previous study showed that there was no statistically significant association between KLF4 and C-myc expression when stratified by age in patients with esophageal, gastric, 


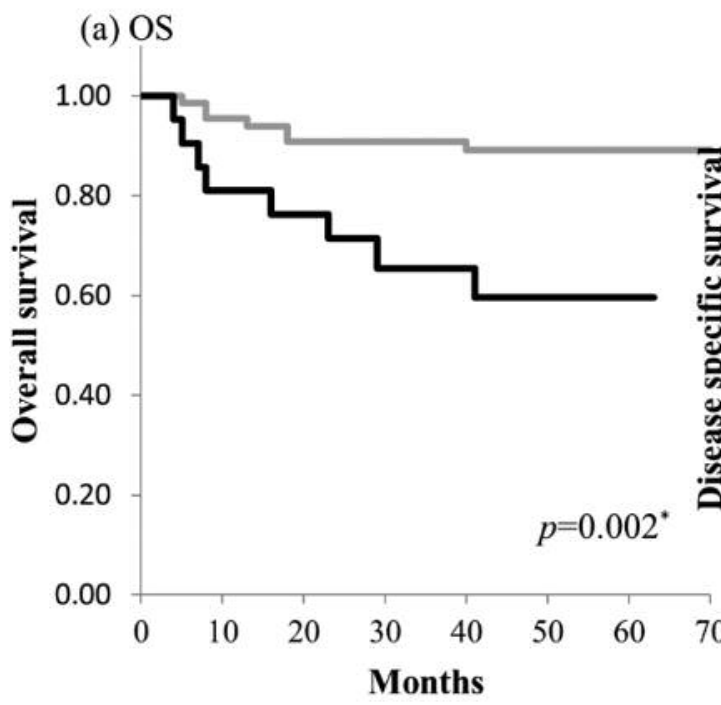

\section{(b) DSS}

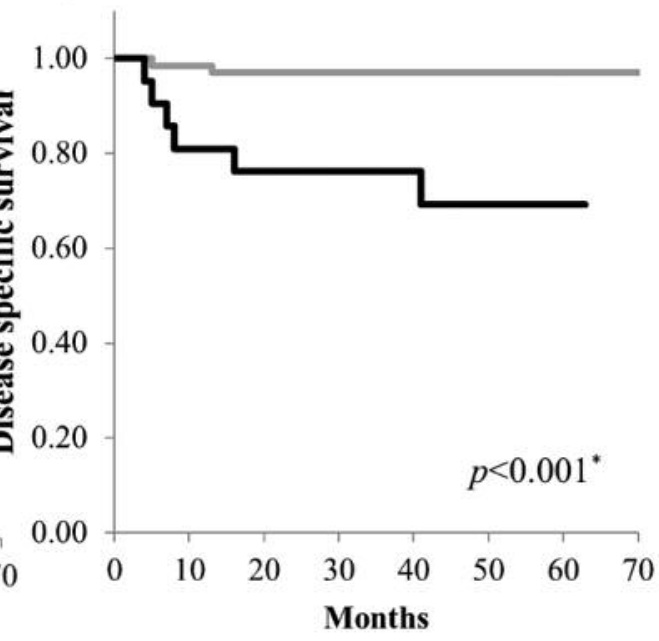

(c) LC

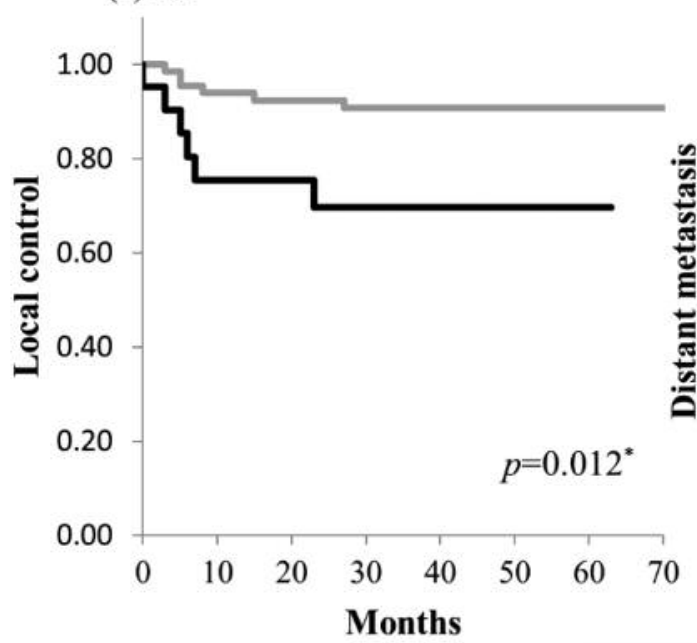

(d) DM

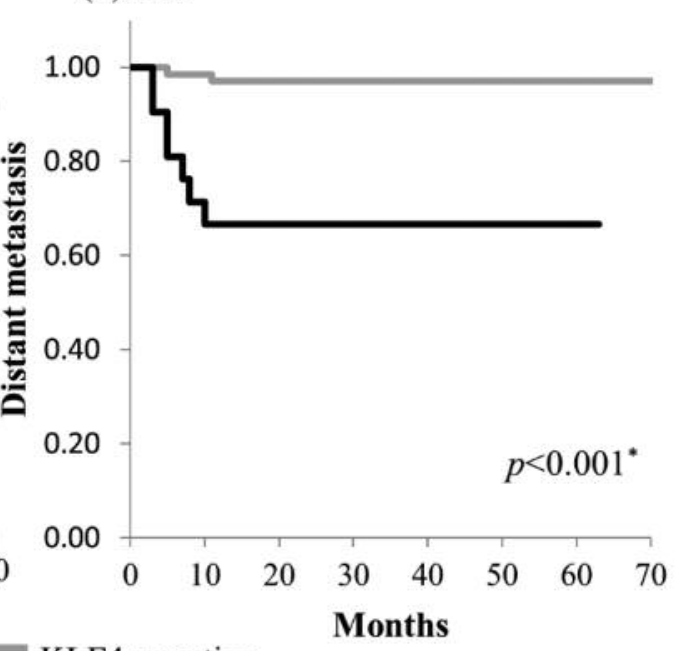

KLF4 negative KLF4 positive

Figure 2. Relationships between (a) OS, (b) DSS, (c) LC, and (d) DM rates of patients with oral squamous cell carcinoma and KLF4 expression level (high or low). *Statistically significant $(p<0.05)$.

or lung cancer (24-26). Additionally, a relationship between increased age and KLF4 expression in breast cancer patients has been identified (27). In patients with OSCC, no differences in KLF4 or C-myc expression were found when stratified by age or exposure to tobacco $(9,20,28)$. In the present study, KLF4 and C-myc expression were significantly associated with age $<65$ years, a finding inconsistent with previous reports. To the best of our knowledge, difference in KLF4 expression levels by age group has not been previously reported. A previous study showed that $\mathrm{C}$-myc expression was significantly different between patients with and without tobacco exposure (1). The present study also showed an association between $\mathrm{C}$ myc and tobacco.

SOX2 and OCT4 have been significantly associated with poor tumor differentiation in esophageal and breast cancers $(4,15,29)$, while in oral cancer, SOX2 and OCT4 have been positively associated with lymph node metastasis and poorer tumor differentiation (30-32). In the present study, only OCT4 expression was significantly associated with multiple neck metastases and poor tumor differentiation, consistent with its reported association with lymph node metastasis and 
(a) $\mathrm{OS}$

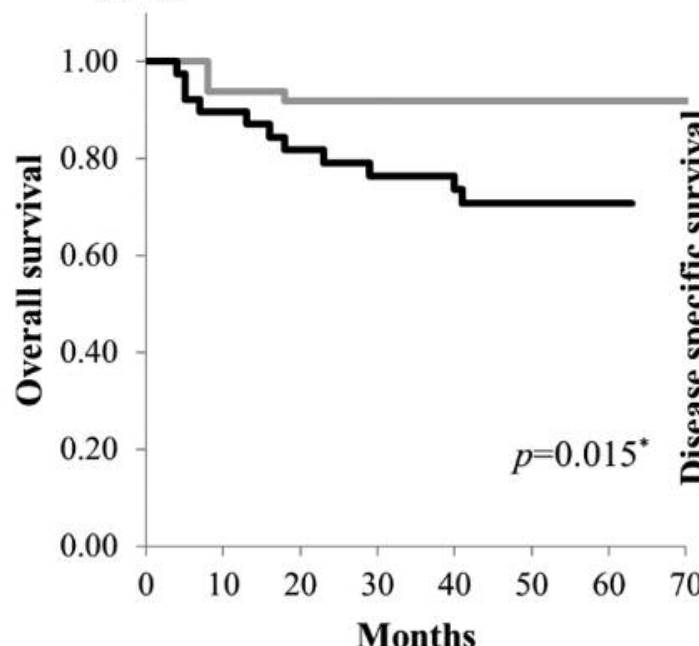

Months (b) DSS

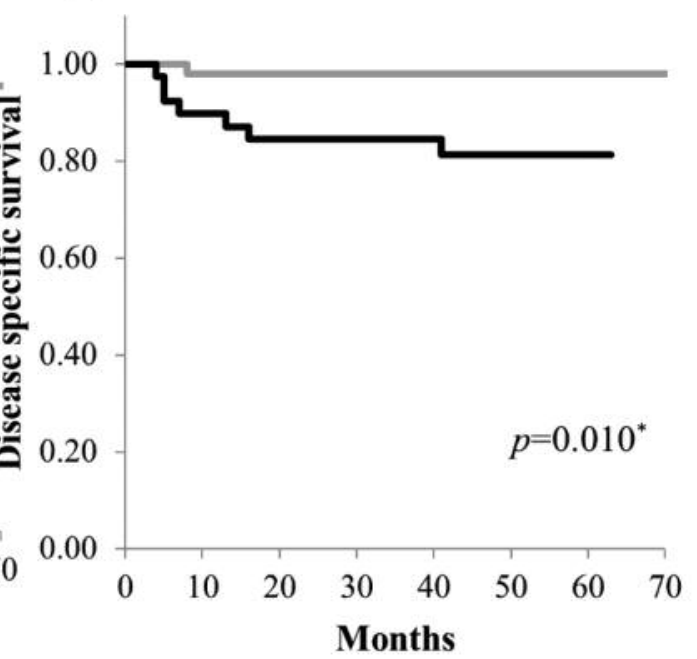

(c) LC

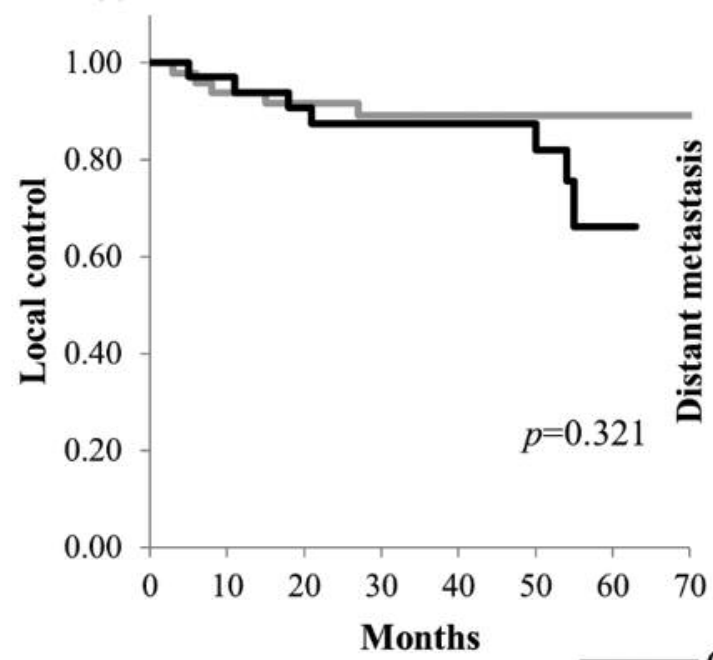

(d) DM

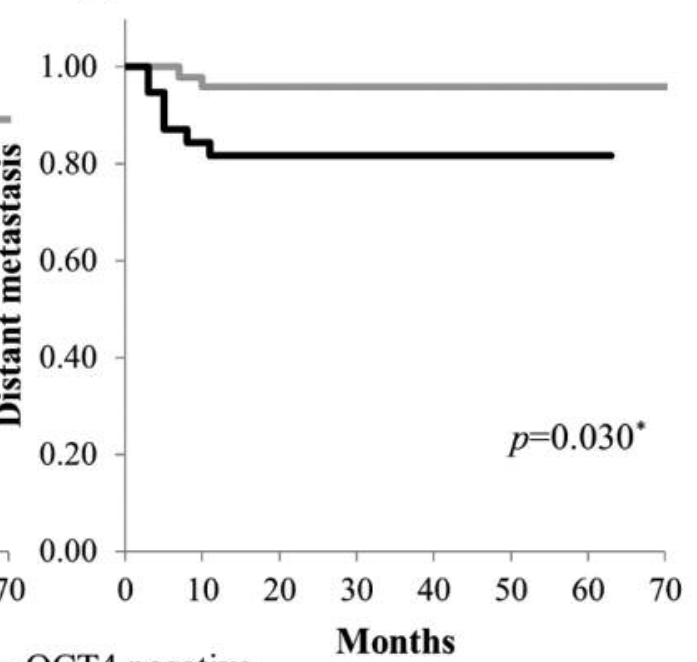

Figure 3. Relationships between (a) OS, (b) DSS, (c) LC, and (d) DM rates of patients with oral squamous cell carcinoma and OCT4 expression level (high or low). *Statistically significant $(p<0.05)$.

tumor stage. Together, these data suggest that OCT4 may be involved in tumor metastasis.

Studies have shown that SOX2 and OCT4 are important transcription factors involved in maintaining self-renewal and pluripotency in CSCs; high SOX2 and OCT4 expression might also be associated with carcinogenesis in various cancers $(11,33,34)$. High OCT4 expression has been associated with poor disease-free survival and OS in esophageal and cervical cancer $(11,34)$. Additionally, OCT4 may contribute to unfavorable prognosis in malignancies of the stomach, esophagus, lungs, and oral cavity by increasing tumor invasion and metastasis and by decreasing tumor differentiation (11, 31-32, 35-36). SOX2 has previously been associated with DM and DSS in oral cancer $(9,32)$, and OCT4 expression has been associated with poor tumor differentiation, tumor invasion, and metastasis (30-31). Conversely, high SOX2 expression has been shown to be associated with increased survival rates (37). Our findings indicate that high SOX2 and OCT4 expression are significantly associated with decreased 3-year DSS and DM rates of OSCC patients compared with those having low expression of these factors, consistent with the previous studies described above. 

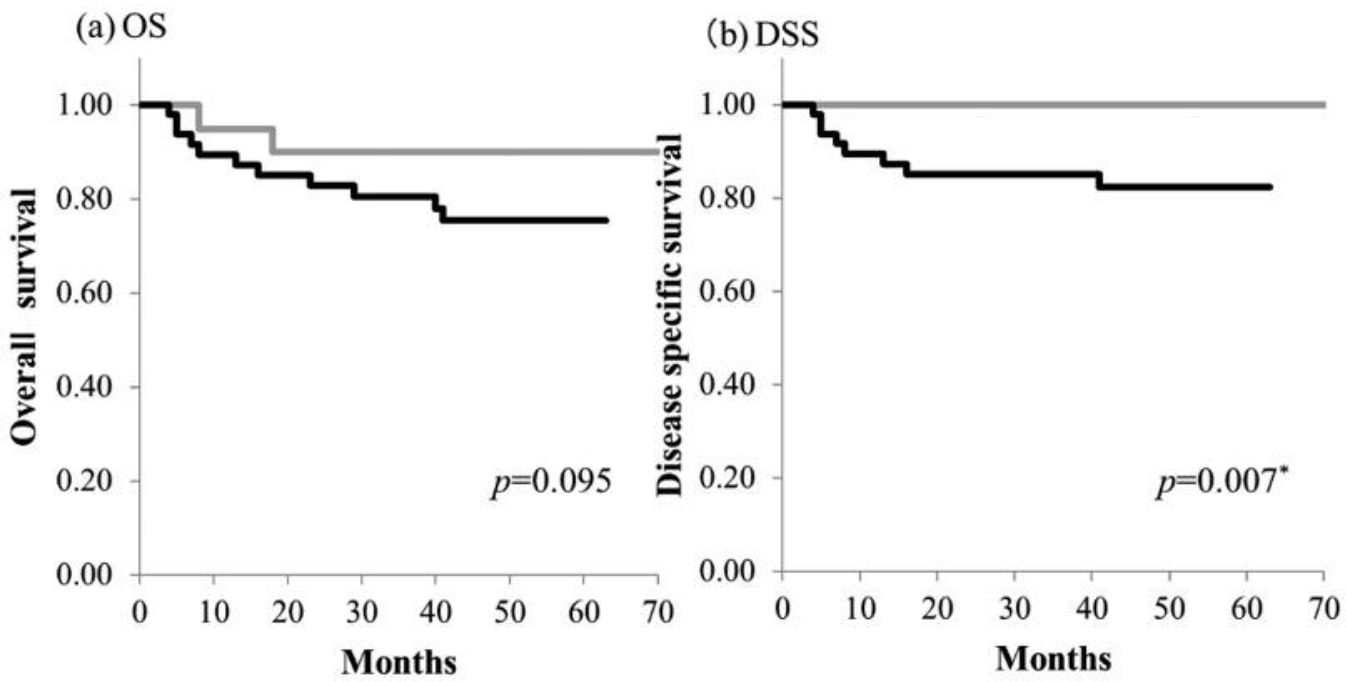

(c) LC

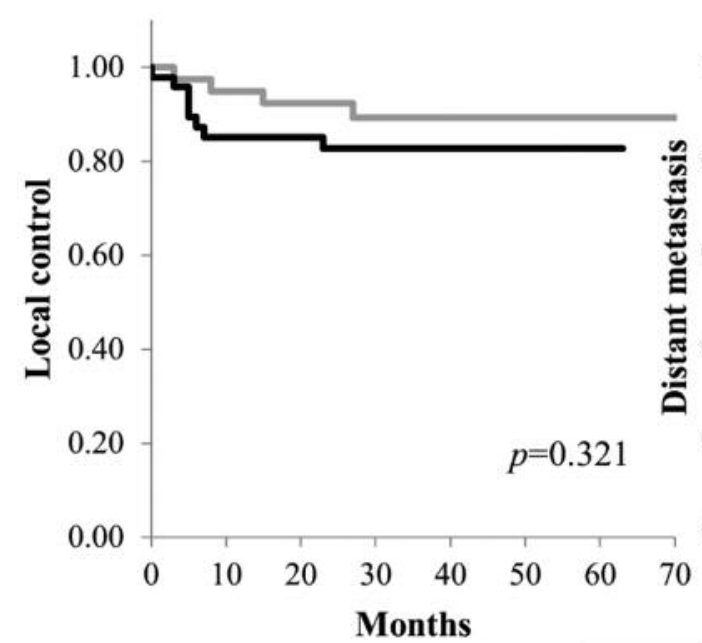

(d) DM

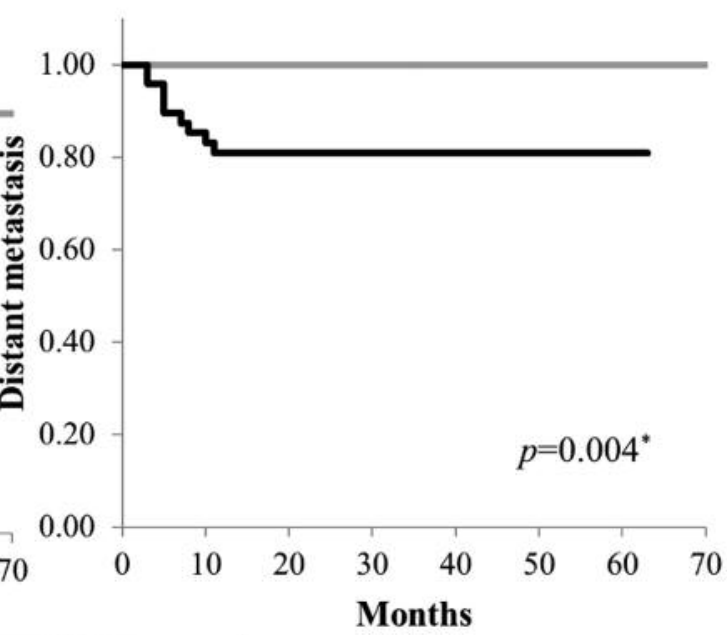

SOX2 negative

SOX2 positive

Figure 4. Relationships between (a) OS, (b) DSS, (c) LC, and (d) DSS rates of patients with oral squamous cell carcinoma and SOX2 expression level (high or low). *Statistically significant $(p<0.05)$.

C-myc is a member of the Myc family of protooncogenes, that also includes L-myc and N-myc (23). The $\mathrm{C}$-myc protein is a transcription factor, aberrant expression of which is sufficient to induce cell cycle progression. Moreover, C-myc is associated with poor tumor prognosis and CSC self-renewal (1). In esophageal squamous cell carcinoma, C-myc expression was significantly correlated with invasion depth, lymph node metastasis, and poor prognosis (38), while in oral cancer, C-myc overexpression was a clear indicator of poor prognosis and stage in locally advanced tumors (39). However, C-myc did not correlate with 5-year survival in patients with oral and oropharyngeal carcinomas (40). Similarly, our results did not show any significant association between C-myc expression and 3-year DSS, although there was a tendency toward poorer prognoses in the high-C-myc expression group.

KLF4 is a bi-functional transcription factor that has opposing roles in different cancers, either as a tumor suppressor or oncogene. Increased KLF4 expression has been associated with poor prognoses in early-stage breast cancer, skin cancer, and HNSCC; furthermore, persistent KLF4 expression induced multi-drug resistance and was associated with progression and poor prognosis in HNSCC (20). Additionally, high KLF4 staining has been 
(a) OS
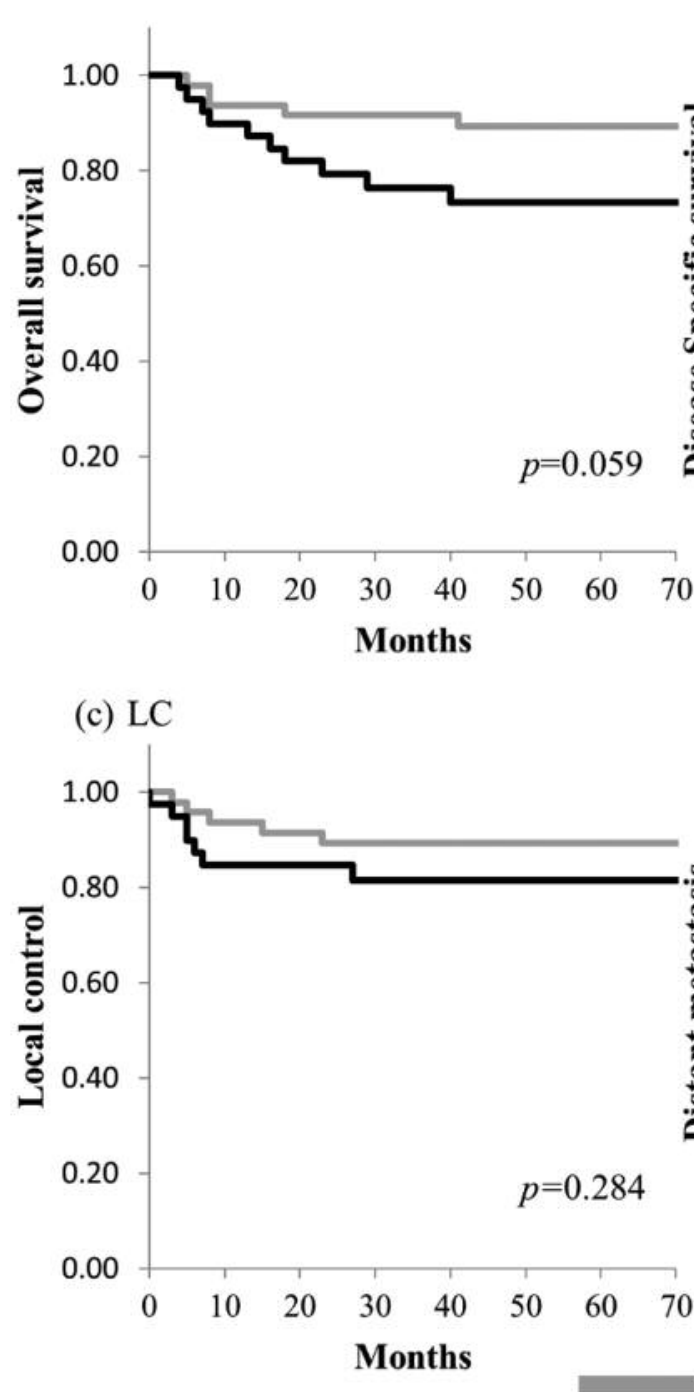

(b) DSS

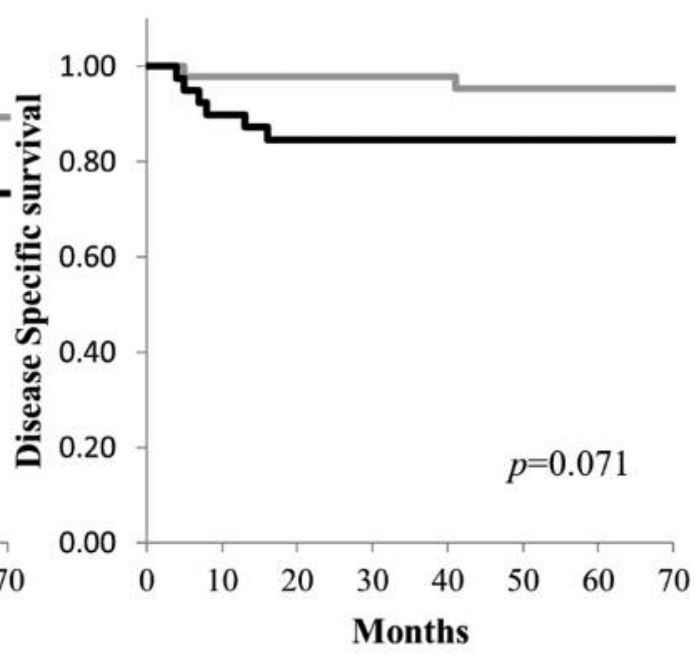

(d) $\mathrm{DM}$

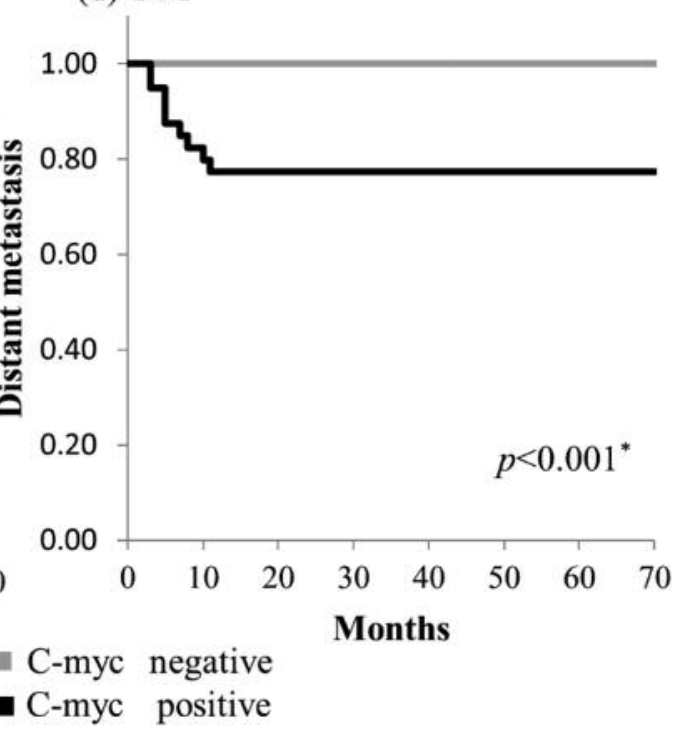

Figure 5. Relationships between (a) OS, (b) DSS, (c) LC, and (d) DSS rates of patients with oral squamous cell carcinoma and C-myc expression level (high or low). *Statistically significant $(p<0.05)$.

significantly associated with moderately and poorly differentiated tumors and metastasis in human skin cancer (41). KLF4 overexpression in the skin has also been shown to result in hyperplasia and dysplasia, eventually leading to squamous cell carcinoma (18). Furthermore, KLF4 has been associated with low 3-year DSS rates in patients with advanced HNSCC. Additionally, KLF4 has been associated with DM and disease-free survival rates. KLF4 also has a statistically significant association with neck cancer recurrence, and a multivariate analysis showed that KLF4 was an independent predictor for worse DSS (20). In the present study, decreased 3-year OS, DSS, LC, and DM rates among OSCC patients were significantly associated with high KLF4 expression compared to low expression. Regarding DSS rates, our results were consistent with those of previous studies. Our multivariate analysis also revealed that $\mathrm{KLF} 4(\mathrm{OR}=10.28)$ and tumor differentiation $(\mathrm{OR}=14.85)$ were the most predictive factors for DSS $(p<0.01)$. Therefore, in preoperative oral cancer biopsies, higher KLF4 and poor differentiation may represent clinically effective predictors of the prognosis of oral cancer. 
Conversely, KLF4 has been shown to be expressed in the cytoplasm and nuclei of gastric cancer cells, and loss of KLF4 has been associated with a poor prognosis (42). KLF4 has been reported to be predominantly located in the nuclei of oral cancer cells, and decreased KLF4 has been associated with poor prognosis (28). Furthermore, several functional investigations have indicated that decreased KLF4 expression was associated with the initiation and formation of precancerous lesions in various tissues (17, 43-47). Increased KLF4 expression induced cell-cycle arrest and apoptosis in gastric cancer cells, and KLF4 has been shown to induce apoptosis in bladder cancer, colon cancer, and leukemia cells (48). However, the apoptotic mechanism induced by KLF4 has not yet been demonstrated. In summary, further investigations are necessary to clarify the association between KLF4 expression and prognosis.

In conclusion, the expression levels of four iPS-related genes (SOX2, KLF4, OCT4, and C-myc) were investigated in tumor samples from patients with OSCC, and the associations between their expression levels and patient outcomes were examined. Our findings indicate that high expression of these genes may be associated with DM in OSCC, and future postoperative pathological studies of iPS-related gene expression may therefore influence treatment strategy, specifically the control of distant metastasis. Furthermore, high KLF4 expression and tumor differentiation were found to be independent poor prognostic factors for OSCC. Therefore, in preoperative biopsies, higher KLF4 expression and poor differentiation may represent clinically effective predictors for the prognosis of oral cancer.

\section{Conflicts of Interest}

The Authors declare that they have no competing interests regarding this study.

\section{Authors' Contributions}

DT and TH conceived and designed the experiments; YM performed the experiments; EI, IS, and RA provided experimental assistance; YM, DT, and TH analyzed the data; TU contributed reagents, materials, and analysis tools; TU provided advice on experimental techniques; YM and TH wrote the manuscript; TK proofread the manuscript; AS, AM, and TK supervised all aspects of this study.

\section{Acknowledgements}

The Authors thank James P. Mahaffey, PhD, and Clare Cox, PhD, from Edanz Group (www.edanzediting.com/ac) for editing a draft of this manuscript. This study was funded by JSPS KAKENHI (Grant Number 16K20575). The funders had no role in the design of the study, the collection, analysis and interpretation of data, or manuscript writing. The Ethics Committee of Kobe University Hospital approved this study (permission number: 180171), and written informed consent was obtained from all patients.

\section{References}

1 Pérez-Sayáns M, Suárez-Peñaranda JM, Padín-Iruegas E, Gayoso-Diz P, Reis-De Almeida M, Barros-Angueira F, Gándara-Vila P, Blanco-Carrión A and García-García A: Quantitative determination of c-myc facilitates the assessment of prognosis of OSCC patients. Oncol Rep 31: 1677-1682, 2014. PMID: 24573767, DOI: 10.3892/or.2014.3040

2 Teppo S, Sundquist E, Vered M, Holappa H, Parkkisenniemi J, Rinaldi T, Lehenkari P, Grenman R, Dayan D, Risteli J, Sato T and Nyberg P: The hypoxic tumor microenvironment regulates invasion of aggressive oral carcinoma cells. Exp Cell Res 319: 376-389, 2013. PMID: 23262025, DOI: 10.1016/j.yexcr. 2012.12.010

3 Reya T, Morrison SJ, Clarke MF and Weissman IL: Stem cells, cancer, and cancer stem cells. Nature 414: 105-111, 2001. PMID: 11689955, DOI: $10.1038 / 35102167$

4 Gwak JM, Kim M, Kim HJ, Jang MH and Park SY: Expression of embryonal stem cell transcription factors in breast cancer: Oct4 as an indicator for poor clinical outcome and tamoxifen resistance. Oncotarget 8: 36305-36318, 2017. PMID: 28422735, DOI: 10.18632 /oncotarget.16750.

5 Takeda D, Hasegawa T, Ueha T, Iwata E, Harada R, Sakakibara A, Kawamoto T, Minamikawa T, Sakai Y and Komori T: Induced pluripotent-stem-cell related genes contribute to de-differentiation in oral squamous cell carcinoma. Anticancer Res 37: 1075-1082, 2017. PMID: 28314267, DOI: 10.21873/ anticanres.11419

6 Qiao B, He B, Cai J and Yang W:The expression profile of Oct4 and Sox2 in the carcinogenesis of oral mucosa. Int J Clin Exp Pathol 7: 28-37, 2014. PMID: 24427323

7 Takahashi $\mathrm{K}$ and Yamanaka S: Induction of pluripotent stem cells from mouse embryonic and adult fibroblast cultures by defined factors. Cell 126: 663-676, 2006. PMID: 16904174, DOI: $10.1016 /$ j.cell.2006.07.024

8 Takahashi K, Tanabe K, Ohnuki M, Narita M, Ichisaka T, Tomoda $\mathrm{K}$ and Yamanaka S: Induction of pluripotent stem cells from adult human fibroblasts by defined factors. Cell 131: 861872, 2007. PMID: 18035408, DOI: 10.1016/j.cell.2007.11.019

9 Yoshihama R, Yamaguchi K, Imajyo I, Mine M, Hiyake N, Akimoto N, Kobayashi Y, Chigita S, Kumamaru W, Kiyoshima T, Mori Y and Sugiura T: Expression levels of SOX2, KLF4 and brachyury transcription factors are associated with metastasis and poor prognosis in oral squamous cell carcinoma. Oncol Lett 11: 1435-1446, 2016. PMID: 26893757

10 Okita K, Ichisaka T and Yamanaka S: Generation of germlinecompetent induced pluripotent stem cells. Nature 448: 313-317, 2007. PMID: 17554338, DOI: 10.1038/nature05934

$11 \mathrm{He}$ W, Li K, Wang F, Qin YR and Fan QX: Expression of OCT4 in human esophageal squamous cell carcinoma is significantly associated with poorer prognosis. World J World J Gastroenterol 18: 712-719, 2012. PMID: 22363145, DOI: 10.3748/wjg.v18.i7.712.

12 Neumann J, Bahr F, Horst D, Kriegl L, Engel J, Luque RM, Gerhard M, Kirchner T and Jung A: SOX2 expression correlates with lymph-node metastases and distant spread in right-sided colon cancer. BMC cancer 11: 518, 2011. PMID: 22168803, DOI: $10.1186 / 1471-2407-11-518$

13 Sholl LM, Barletta JA, Yeap BY, Chirieac LR and Hornick JL: Sox 2 protein expression is an independent poor prognostic indicator in stage I lung adenocarcinoma. Am J Surg Pathol 34: 1193-1198, 2010. PMID: 20631605, DOI: 10.1097/ PAS.0b013e3181e5e024 
14 Ruan J, Wei B, Xu Z, Yang S, Zhou Y, Yu M, Liang J, Jin K, Huang $\mathrm{X}, \mathrm{Lu} \mathrm{P}$ and Cheng $\mathrm{H}$ : Predictive value of Sox2 expression in transurethral resection specimens in patients with T1 bladder cancer. Med Onco 30: 445, 2013. PMID: 23307254, DOI: $10.1007 / \mathrm{s} 12032-012-0445-\mathrm{Z}$

15 Wang Q, He W, Lu C, Wang Z, Wang J, Giercksky KE, Nesland JM and Suo Z: Oct3/4 and Sox 2 are significantly associated with an unfavorable clinical outcome in human esophageal squamous cell carcinoma. Anticancer Res 29: 1233-1241, 2009. PMID: 19414369

16 Foster KW, Ren S, Louro ID, Lobo-Ruppert SM, McKie-Bell P, Grizzle W, Hayes MR, Broker TR, Chow LT and Ruppert JM: Oncogene expression cloning by retroviral transduction of adenovirus E1A-immortalized rat kidney RK3E cells: transformation of a host with epithelial features by c-MYC and the zinc finger protein GKLF. Cell Growth Differ 10: 423-434, 1999. PMID: 10392904

17 Evans PM and Liu C: Roles of Krüpel-like factor 4 in normal homeostasis, cancer and stem cells. Acta Biochim Biophys Sin (Shanghai) 40: 554-564, 2008. PMID: 18604447

18 Huang CC, Liu Z, Li X, Bailey SK, Nail CD, Foster KW, Frost AR, Ruppert JM and Lobo-Ruppert SM: KLF4 and PCNA identify stages of tumor initiation in a conditional model of cutaneous squamous epithelial neoplasia. Cancer Biol Ther 4: 1401-1408, 2005. PMID: 16357510

19 Tian Y, Luo A, Cai Y, Su Q, Ding F, Chen H and Liu Z: MicroRNA-10b promotes migration and invasion through KLF4 in human esophageal cancer cell lines. J Biol Chem 285: 79867994, 2010. PMID: 20075075, DOI: 10.1074/jbc.M109.062877

20 Tai SK, Yang MH, Chang SY, Chang YC, Li WY, Tsai TL, Wang YF, Chu PY and Hsieh SL: Persistent Krüppel-like factor 4 expression predicts progression and poor prognosis of head and neck squamous cell carcinoma. Cancer Sci 102: 895-902, 2011. PMID: 21219537, DOI: 10.1111/j.1349-7006.2011.01859.x

21 Talebi A, Kianersi K and Beiraghdar M: Comparison of gene expression of SOX2 and OCT4 in normal tissue, polyps, and colon adenocarcinoma using immunohistochemical staining. Adv Biomed Res 4: 234, 2015. PMID: 26645019, DOI: $10.4103 / 2277-9175.167958$

22 Chambers I and Tomlinson SR.: The transcriptional foundation of pluripotency. Development 136: 2311-2322, 2009. PMID: 19542351, DOI: $10.1242 /$ dev.024398

23 Segura S, Rozas-Muñoz E, Toll A, Martín-Ezquerra G, Masferrer E, Espinet B, Rodriguez M, Baró T, Barranco C and Pujol RM: Evaluation of MYC status in oral lichen planus in patients with progression to oral squamous cell carcinoma. $\mathrm{Br}$ J Dermatol. 169: 106-114, 2013. PMID: 23461699, DOI: $10.1111 /$ bjd .12303

24 Hashimoto I, Nagata T, Sekine S, Moriyama M, Shibuya K, Hojo S, Matsui K, Yoshioka I, Okumura T, Hori T, Shimada Y and Tsukada K: Prognostic significance of KLF4 expression in gastric cancer. Oncol Lett 13: 819-826, 2017. PMID: 28356964 , DOI: $10.3892 / \mathrm{ol} .2016 .5499$

25 Shimada Y, Okumura T, Sekine S, Moriyama M, Sawada S, Matsui K, Yoshioka I, Hojo S, Yoshida T, Nagata T, Fukuoka J and Tsukada K: Expression analysis of iPS cell - inductive genes in esophageal squamous cell carcinoma by tissue microarray. Anticancer Res 32: 5507-5514, 2012. PMID: 23225459

26 Fadous-Khalifé MC, Aloulou N, Jalbout M, Hadchity J, Aftimos G, Paris F and Hadchity E: Krüppel-like factor 4: A new potential biomarker of lung cancer. Mol Clin Oncol 5: 35-40, 2016. PMID: 27330761, DOI: 10.3892/mco.2016.883

27 Chen CJ, Lin SE, Lin YM, Lin SH, Chen DR and Chen CL: Association of expression of kruppel-like factor 4 and kruppellike factor 5 with the clinical manifestations of breast cancer. Pathol Oncol Res 18: 161-168, 2012. PMID: 21674249, DOI: 10.1007/s12253-011-9422-7

28 Chen CJ, Hsu LS, Lin SH, Chen MK, Wang HK, Hsu JD, Lee $\mathrm{H}$ and Yeh KT: Loss of nuclear expression of Krüppel-like factor 4 is associated with poor prognosis in patients with oral cancer. Hum Pathol 43: 1119-1125, 2012. PMID: 22209344, DOI: 10.1016/j.humpath.2011.09.003

29 Tian T, Zhang Y, Wang S, Zhou J and Xu S: Sox2 enhances the tumorigenicity and chemoresistance of cancer stem-like cells derived from gastric cancer. J Biomed Res 26: 336-345, 2012. PMID: 23554769, DOI: 10.7555/JBR.26.20120045

30 Ravindran G, Sawant SS, Hague A, Kingsley K and Devaraj H: Association of differential $\beta$-catenin expression with Oct-4 and Nanog in oral squamous cell carcinoma and their correlation with clinicopathological factors and prognosis. Head Neck 37: 982-993, 2014. PMID: 24700702, DOI: 10.1002/hed.23699

31 Chiou SH, Yu CC, Huang CY, Lin SC, Liu CJ, Tsai TH, Chou $\mathrm{SH}$, Chien CS, Ku HH and Lo JF: Positive correlations of Oct4 and Nanog in oral cancer stem-like cells and high-grade oral squamous cell carcinoma. Clin Cancer Res 14: 4085-4095, 2008. PMID: 18593985, DOI: 10.1158/1078-0432.CCR-07-4404

32 Lee SH, Oh SY, Do SI, Lee HJ, Kang HJ, Rho YS, Bae WJ and Lim YC: SOX2 regulates self-renewal and tumorigenicity of stem-like cells of head and neck squamous cell carcinoma. Br J Cancer 111: 2122-2130, 2014. PMID: 25321191, DOI: 10.1038/bjc.2014.528

33 Wang YD, Cai N, Wu XL, Cao HZ, Xie LL and Zheng PS: OCT4 promotes tumorigenesis and inhibits apoptosis of cervical cancer cells by miR-125b/BAK1 pathway. Cell Death Dis 4: e760, 2013. PMID: 23928699, DOI: 10.1038/cddis.2013.272

34 Kim BW, Cho H, Choi CH, Ylaya K, Chung JY, Kim JH and Hewitt SM: Clinical significance of OCT4 and SOX2 protein expression in cervical cancer. BMC Cancer 15: 1015, 2015. PMID: 26706028, DOI: 10.1186/s12885-015-2015-1

35 Chiou SH, Wang ML, Chou YT, Chen CJ, Hong CF, Hsieh WJ, Chang HT, Chen YS, Lin TW, Hsu HS and Wu CW: Coexpression of Oct4 and Nanog enhances malignancy in lung adenocarcinoma by inducing cancer stem cell-like properties and epithelialmesenchymal transdifferentiation. Cancer Res 70: 10433-10444, 2010. PMID: 21159654, DOI: 10.1158/0008-5472.CAN-10-2638

36 Kong D, Su G, Zha L, Zhang H, Xiang J, Xu W, Tang Y and Wang Z: Coexpression of HMGA2 and Oct4 predicts an unfavorable prognosis in human gastric cancer. Med Oncol 31: 130, 2014. PMID: 25037576, DOI: 10.1007/s12032-014-0130-5

37 Wilbertz T, Wagner P, Petersen K, Stiedl AC, Scheble VJ, Maier S, Reischl M, Mikut R, Altorki NK, Moch H, Fend F, Staebler A, Bass AJ, Meyerson M, Rubin MA, Soltermann A, Lengerke $\mathrm{C}$ and Perner S: SOX2 gene amplification and protein overexpression are associated with better outcome in squamous cell lung cancer. Mod Pathol 24: 944-953, 2011. PMID: 21460799, DOI: 10.1038/modpathol.2011.49

38 Wang W, Xue L and Wang P: Prognostic value of $\beta$-catenin, cmyc, and cyclin D1 expressions in patients with esophageal squamous cell carcinoma. Med Oncol 28: 163-169, 2011. PMID: 20143187, DOI: 10.1007/s12032-010-9436-0 
39 Vora HH, Shah NG, Patel DD, Trivedi TI and Chikhlikar PR: Prognostic significance of biomarkers in squamous cell carcinoma of the tongue: multivariate analysis. J Surg Oncol 82: 34-50, 2003. PMID: 12501167, DOI: 10.1002/jso.10183

40 Tsuzuki H, Sunaga H, Ito T, Narita N, Sugimoto C and Fujieda $\mathrm{S}$ : Reliability of platelet-derived endothelial cell growth factor as a prognostic factor for oral and oropharyngeal carcinomas. Arch Otolaryngol Head Neck Surg 131: 1071-1078, 2005. PMID: 16365220, DOI: 10.1001/archotol.131.12.1071

41 Chen YJ, Wu CY, Chang CC, Ma CJ, Li MC and Chen CM: Nuclear Krüppel-like factor 4 expression is associated with human skin squamous cell carcinoma progression and metastasis. Cancer Biol Ther 7: 777-782, 2008. PMID: 18376139

42 Zhang N, Zhang J, Shuai L, Zha L, He M, Huang Z and Wang $Z$ : Krüppel-like factor 4 negatively regulates $\beta$-catenin expression and inhibits the proliferation, invasion and metastasis of gastric cancer. Int J Oncol 40: 2038-2048, 2012. PMID: 22407433, DOI: $10.3892 /$ ijo.2012.1395

43 Liu Z, Yang H, Luo W, Jiang Q, Mai C, Chen Y, Zhen Y, Yu X, Long $\mathrm{X}$ and Fang W: Loss of cytoplasmic KLF4 expression is correlated with the progression and poor prognosis of nasopharyngeal carcinoma. Histopathology 63: 362-370, 2013. PMID: 23758499, DOI: 10.1111/his.12176

44 Li J, Zheng H, Yu F, Yu T, Liu C, Huang S, Wang TC and Ai W: Deficiency of the Kruppel-like factor KLF4 correlates with increased cell proliferation and enhanced skin tumorigenesis. Carcinogenesis 33: 1239-1246, 2012. PMID: 22491752, DOI: $10.1093 /$ carcin/bgs 143
45 Liu Y, Zhang C, Fan J, Xiao L, Yin B, Zhou L and Xia S: Comprehensive analysis of clinical significance of stem-cell related factors in renal cell cancer. World J Surg Oncol 9: 121, 2011. PMID: 21982273, DOI: 10.1186/1477-7819-9-121

$46 \mathrm{Hu}$ W, Hofstetter WL, Li H, Zhou Y, He Y, Pataer A, Wang L, Xie K, Swisher SG and Fang B: Putative tumor-suppressive function of Kruppel-like factor 4 in primary lung carcinoma. Clin Cancer Res 15: 5688-5695, 2009. PMID: 19737957, DOI: 10.1158/1078-0432.CCR-09-0310

47 Yang WT and Zheng PS: Krüppel-like factor 4 functions as a tumor suppressor in cervical carcinoma. Cancer 118: 3691-3702, 2012. PMID: 22170594, DOI: 10.1002/cncr.26698

48 Wei D, Gong W, Kanai M, Schlunk C, Wang L, Yao JC, Wu TT, Huang $\mathrm{S}$ and Xie K: Drastic down-regulation of Krüppel-like factor 4 expression is critical in human gastric cancer development and progression. Cancer Res 65: 2746-2754, 2005. PMID: 15805274, DOI: 10.1158/0008-5472.CAN-04-3619
Received January 8, 2019

Revised January 24, 2019

Accepted January 25, 2019 